International Review of Social History 46 (200I), pp. 227-255

(C) 200 I Internationaal Instituut voor Sociale Geschiedenis

\title{
SURVEY
}

\section{Studies on Anticlericalism in Contemporary Spain}

\author{
Manuel Pérez Ledesma
}

Anticlericalism was a decisive trend in Spanish political, social, and cultural life from the beginning of the nineteenth century until the Spanish Civil War. It is true that anticlerical movements also existed in other European states, but the confrontations were much more intense in Spain. José M. Sánchez recalls this in a concise summary of the violence unleashed by these struggles: from I 822 to 1936 , at least 235 members of the clergy were assassinated and around 500 churches and religious centres were burned. In addition, in the three years of the Civil War, almost 7,000 priests, monks and nuns suffered the same fate. Despite this, until a few years ago there were frequent complaints about the scant attention paid by Spanish historians to this trend. Julio de la Cueva Merino referred to this lack of research, and even to the "historiographic vacuum", in a summary of publications on the subject which appeared in I99I. Three years later, Pilar Salomón mentioned the "absence of fruitful bibliographic production", and, as recently as 1997, Rafael Cruz spoke of a "shortage of works", or at least a very scarce production of monographs. ${ }^{\text {I }}$ Outside the field of history, anthropologists such as David Gilmore and Manuel Delgado have likewise criticized the lack of interest of their colleagues in the face of what Gilmore defined as "as powerful a social and ideological phenomenon as devotion", and which should deserve the same intellectual consideration. ${ }^{2}$

These criticisms are at least partly justified. Indeed, at the beginning of the nineties, Julio de la Cueva only found eight works directly dedicated to the study of Spanish anticlericalism, which, moreover, included some already rather antiquated summaries. The impression of a vacuum should not, however, be exaggerated. In actual fact, although their main theme was not anticlericalism, many works have tackled it, at least indirectly, in studying other subjects, such as the history of the Catholic Church and its relations with the Spanish state, the evolution of freemasonry and of

I. The figures, in Sánchez, Spanish Civil War, p. 49. The valuations, in de la Cueva Merino, "La cuestión clerical-anticlerical", p. i 2 I; Salomón, "Poder y ética", p. I 26; and Cruz, "Los estudios sobre anticlericalismo", p. 2 I 9.

2. Gilmore, "Anticlericalism of the Andalusian Rural Proletarians", p. 482. 
organizations of freethinkers, conflicts on education, the development of science and culture and, finally, nineteenth-century literary creations whose protagonists were members of the clergy. Even more important is the fact that, before the nineties, certain fundamental theses had already been formulated and various lines of research initiated, these still being valid today. It is therefore essential to analyse this prior history in order to discuss the most recent historiographical production with the necessary rigour.

\section{THE CLERICAL HISTORIOGRAPHY: IN SEARCH OF CULPRITS}

Starting in the I960s, the historians of the Church, themselves mostly members of religious organizations, were undoubtedly the first to deal with the anticlerical movements. The well-known book by Antonio Montero, Historia de la persecución religiosa en España, 1936-1939, a sort of martyrology from which all subsequent calculations are taken, paved the way. In his analysis of the causes of anticlericalism, in which he, of course, exempted the Church from any responsibility, Montero referred to four factors which, in his opinion, were decisive: the antireligious policy inherited from the nineteenth century, the attraction of the freemasons, the success of the revolutionary working-class movement, and the correlative scarce introduction of social Catholicism. Both for Montero and for most of the historians that we can consider as "clerical", the main responsibility lay with the liberal or republican intellectuals and politicians, who used the press to encourage and incite an "ardent hatred of the Church" (Palacio Atard) and the "violent sectarianism of the masses" (Gómez Molleda). Cárcel Ortí explains that intellectual and popular anticlericalism were closely linked: "when the people looted, burned and destroyed holy buildings, or when they assassinated priests, they were putting into practice the instructions received from political leaders in their demagogic street and parliamentary speeches". This relationship became even closer during the Second Republic, when the laicist legislation of the first two years was the starting point for the burning of churches and assassination of ecclesiastics during the weeks after the military rising. ${ }^{3}$

Although in subsequent works, partly due to the influence of the changes of attitude of the Catholic Church in recent decades, other ecclesiastical historians have sometimes referred to the "errors" of the Church, the main responsibility continues to be attributed to the laic intellectuals and to their influence on the anticlerical masses. The most

3. Montero, La persecución religiosa en España, pp. 2-21; Gómez Molleda, Los reformadores de la España contemporánea, pp. 427-430; Cárcel Ortí, La persecución religiosa en España, pp. 9I95 and passim. 
recent example of this historiographic trend, the book by M. Revuelta, El anticlericalismo español en sus documentos, takes this line. Although Revuelta recognizes some "weak points" of the clergy and clericalism: "Being men, after all, the ecclesiastics had their defects", the blame is once again laid on the obsession of the anticlericals with attributing the failings of some of the clergy to the ecclesiastic institution. This is the central point of the argument: the "harangues" full of "falseness and of passion", the "stereotypes" circulated "without any scruples", the lies and the halftruths, the slander and the exaggerations of the anticlericals were, in the author's opinion, the only factors responsible for the confrontation, and the most violent popular sectors "simply applied, at the most intense moments of the political and social revolution, the ideas received from their masters". 4

We should not be surprised that some of these studies conclude by supporting the canonization of all members of the clergy who suffered uncontrolled persecution during the Civil War. The line of argument arises directly from this approach: as the Church was not at all to blame, the murder victims were "martyrs of the faith", pursued by the erring masses just because of their religious beliefs and for being members of the ecclesiastic institution. Taking into account the present attitude of the Catholic Church, it is, moreover, very likely that these requests will achieve their aim. However, independently of the success of these proposals, the clerical historiography has not yet contributed any analysis of special interest in understanding the roots of the phenomenon. In the final analysis, the whole explanation refers to theological ideas on human evil, in particular on the evil of intellectuals who did not have any scruples about circulating exaggerated accusations, and about encouraging an anticlerical culture which ended up by being a factor which triggered off iconoclastic violence.

\section{RATIONALITY AND IRRATIONALITY IN THE BEHAVIOUR OF THE CROWDS}

Apart from the theological lucubrations, it is not easy to explain a movement which led to outbreaks of violence whose terrible consequences we have already mentioned. This is difficult to understand not only at the critical moments of the Civil War, when exhumations and public displays of the bodies of priests, monks, and nuns were added to the fires, lootings and assassinations, but also on previous occasions of less virulence, such as the Tragic Week of 1909, with the actions of crowds dedicated to burning monasteries to protest against the Moroccan war. It is not, therefore, surprising that many contemporaries and quite a few lay historians have

4. Revuelta González, El anticlericalismo español, pp. 8-I2. 


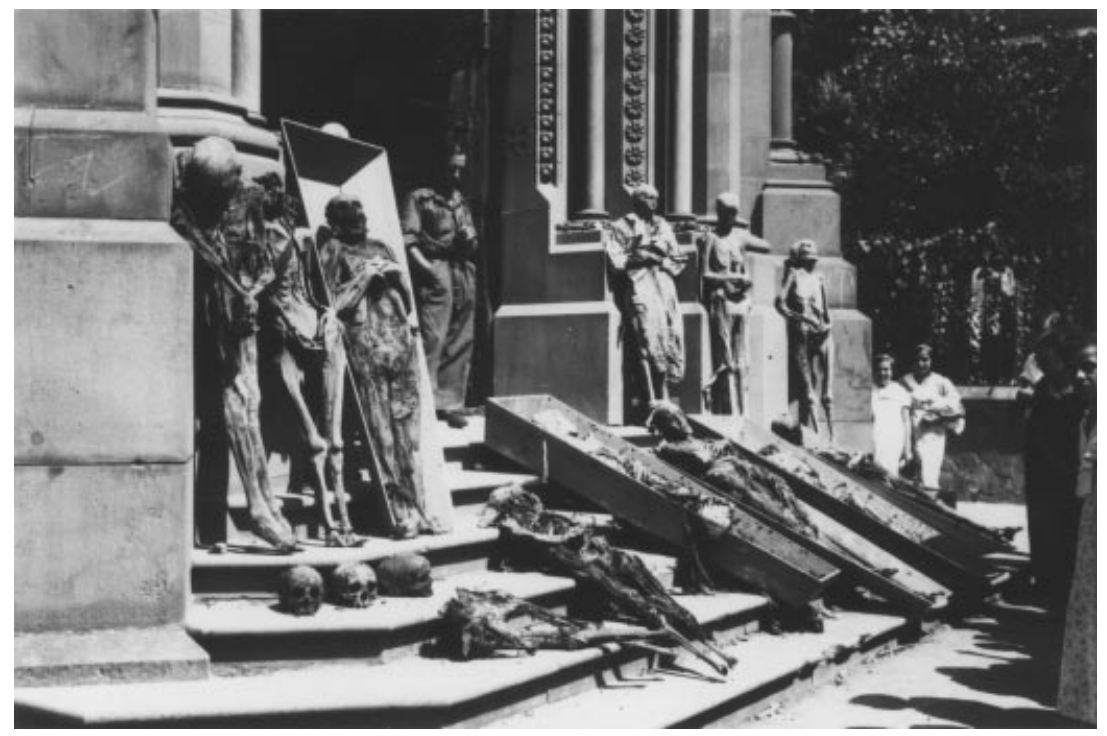

Figure I. Display of exhumed bodies of monks or nuns, Barcelona, I 936.

CNT Collection, International Institute of Social History, Amsterdam

chosen to consider these violent acts as the result of the fanaticism and irrationality of the popular masses: the action - referred to by an official publication of the republican camp during the Civil War - of "unbridled and uncontrolled crowds, who wildly wield their fury against their enemies", or of a people which "having shattered all moral restraints, becomes a dangerous beast which steals, burns, and kills". We could give numerous examples, but in the end the same image always appears: of bloodthirsty, uncontrollable, fanatical and irrational mobs running wild.'

However, this explanation encounters increasing resistance among historians. This is not just because of intellectual conviction - since the works of Thompson and Rudé, the traditional ideas on the irrationality of the masses have fallen into profound disrepute - but also due to a sort of professional obligation, which Bruce Lincoln aptly referred to in his study of revolutionary exhumations: "as scholars we can dismiss no human action as aberrant". First of all, on the contrary, the scholar must analyse "the sources and meanings of even the strangest and most repugnant conduct, which on closer analysis may prove to be far more significant and expressive than the stereotypical automatonic behavior that we think of as comprising normality". ${ }^{6}$

5. There are numerous examples of these opinions in Delgado, La ira sagrada, pp. 25-49.

6. Lincoln, "Revolutionary Exhumations in Spain", p. 246. 
Having accepted this principle, the first studies on anticlericalism which distanced themselves from the cliché of irrationality had to seek a setting in which violent actions were significant and expressive. In a study on the Tragic Week of 1909, Joan Connelly Ullman believed that this could be found in a mixture of economic reasons and calculations of political usefulness. The growth in the number of members of religious orders, and the increase in their wealth from the last decades of the nineteenth century, the ecclesiastic control of education and of charity institutions, and the use of those who attended them as cheap labour for certain productive activities, with the consequent threat of salary reductions, and even of loss of jobs for those who were devoted to those tasks, and, more generally, the working-class conviction that the religious orders were closely linked to the main capitalists, appear in her analysis as the economic roots of working-class anticlericalism, which in 1909 led to the burning of about fifty religious buildings in Barcelona. However, according to this approach, the actions of the leaders of the Radical Party, anxious to avoid a real revolution, also played a decisive role in the outbreak: the radicals "considered arson to be a means to disperse the revolutionary fervour that they themselves had cultivated". ${ }^{7}$

The Tragic Week is not the only anticlerical movement analysed in these terms. The risings of 1834 and I 835 , whose level of violence was much greater (some eighty friars were assassinated in Madrid just in the rising of I7 July I 834), have been explained in similar terms: a popular rejection of the wealth accumulated by the clergy was used by certain well-off classes who wished to take possession of ecclesiastic goods, and who managed to do so immediately, thanks to the confiscatory measures of Mendizábal. ${ }^{8}$ It would not appear to be easy to find other reasons for the anticlerical violence at that time, above all if we take into account that the popular sectors who staged it were still "superstitiously Catholic", as pointed out by Pérez Garzón.

These interpretations were, however, very soon criticized by those who considered them to be excessively reductionist. In an article which immediately became a compulsory work of reference, José Álvarez Junco indicated that "an explanation of anticlericalism in accordance with mere socioeconomic interests or because the Church was automatically seen as the ideological body of the dominant classes" was to ignore the cultural components of anticlerical violence. Although it seems to be contradictory, these components originated in the Christian moral tradition itself, abandoned in practice by the same ecclesiastics who preached it. The radicalism of the popular responses to the "betrayal" of the clergy was due

7. Ullman, La Semana Trágica; the citation on p. 587.

8. Pérez Garzón, "Curas y liberales en la revolución burguesa", pp. 67-100; Santirso, "De repente, el verano de 1835 ”, pp. 3-26. 


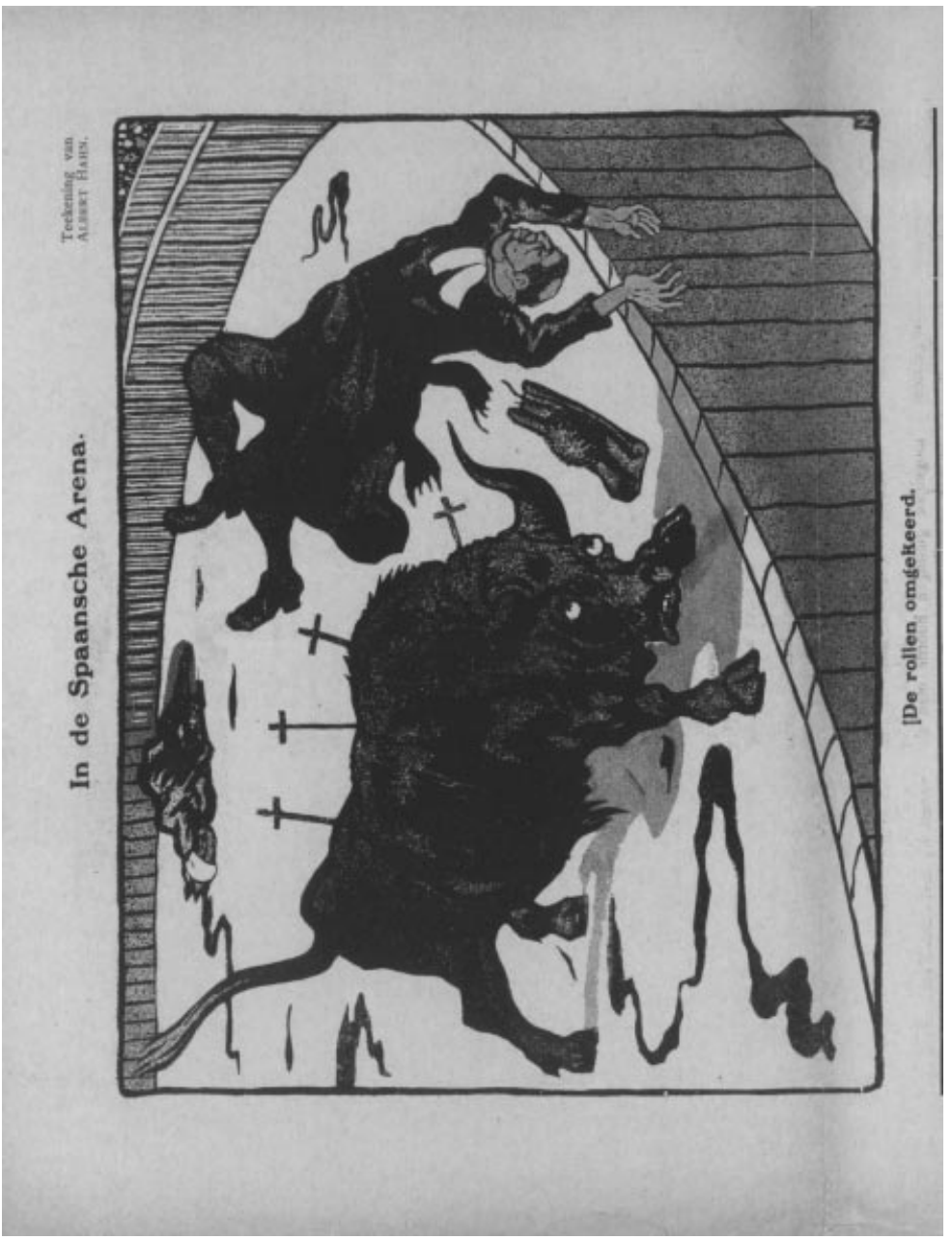

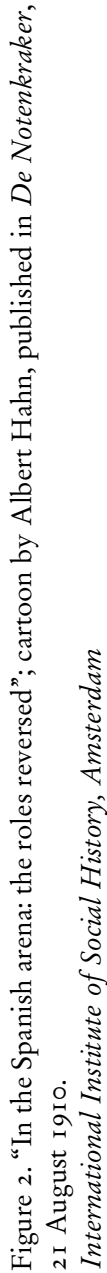


to the "dogmatism and Puritanism" characteristic of this tradition. 9 This was not, in any case, the first time that cultural elements appeared as a fundamental factor to explain anticlericalism: culture, and in particular political culture, had been referred to previously by Romero Maura, characterizing the Tragic Week as the expression of the political philosophy of radical republicanism, shared by most of the Barcelona working class of the time; and also by Álvarez Junco himself, in his examination of the ideological traits of anarchist anticlericalism in Spain. ${ }^{1 \circ} \mathrm{A}$ new development was, however, now the presentation of these elements as the basis of an overall alternative explanation, and also the insistence on the Christian origin of the cultural attitudes of those participating in the risings against the clergy.

\section{SEXUALITY OF THE CLERGY AND SEXUALITY OF THE ANTICLERICALS}

In addition to the replacement of the economic explanations by cultural analyses, already announced in the seventies, a third approach appeared at the same time, half way between social psychology and history. This approach positioned the central core of the explanation in a popular rejection of the sexual behaviour of the clergy, thus pushing the other components of the criticisms and the anticlerical movements into the background.

This approach was not at all new either. Accusations relating to their sexual activities were always present among the traditional attacks on the clergy. There is abundant proof of this starting in the Middle Ages, both in the collections of sayings and in the folk songs and stories passed down from generation to generation by the classical routes of popular culture. ${ }^{\text {I }}$ The press and the anticlerical publications of the nineteenth and twentieth centuries maintained this tradition to a large extent. It is not, therefore, surprising that the historians who have dealt with anticlericalism continually recall the abundance and popularity of these attacks. A new aspect, however, which demands further explanation, is that in some recent

9. Álvarez Junco, "El anticlericalismo en el movimiento obrero", pp. 283-300. An example of Puritan attitudes: in the revolution of October 1934 in Asturias, the assassination of the Brothers of the Christian Schools of Turón was due to the rumours about homosexual practices with their pupils.

10. Romero Maura, La rosa de fuego, pp. 509-542; Álvarez Junco, La ideología política del anarquismo español, pp. 204-2I4. In a subsequent study on republican populism personified by Lerroux in the Barcelona of the beginning of the century, Álvarez Junco likewise insisted on the "cultural, ethical and mythological aspects" of the popular anticlericalism of the time; idem, El Emperador del Paralelo, pp. 386-418.

I r. Medieval legends on the sexuality of the clergy, in Goldberg, Motif. For sayings, Esteban, Refranero anticlerical. 
works the sexuality of the clergy has become the central, and almost the only, interpretative theme of the phenomenon, something that had not previously occurred despite the insistence and reiteration of the criticisms.

Indeed, this new emphasis contrasts with the attitude of the first Spanish scholars who, in the final decades of the last century, devoted themselves to collecting all kinds of demonstrations of popular culture still alive at that time. Of course, the first folklorists recognized that the attacks on the sexual behaviour of the clergy occupied an important place in what one of them, Giner Arivau, defined as "the concept that the people have formed of priests"; but these were not the only, and maybe not the main reproaches. According to the same author, priests were deemed to be "lecherous, gluttonous, mean, hypocritical, frauds and unscrupulous"; in short, they were seen as a "synopsis and compendium of all the capital sins", and not of just one of them. ${ }^{\mathrm{I}}$ It could not even be said that such a negative view was exclusive to the Spanish people, insofar as the same compilers encountered similar attitudes in other European countries. "It would appear", wrote another folklorist, Francisco Rodríguez Marín, "that the Italian people has the same opinion of the clergy as the Andalusian people"; ${ }^{13}$ and as the people of the other Spanish regions, we could add, in view of other collections of popular sayings or songs of the time.

The sexual question again occupied a prominent position in the anticlerical propaganda of the nineteenth and twentieth centuries. It was not, however, the only item of criticism in these texts either, nor even the most important one. The novels, history books or essays devoted to combating the clergy also dealt with other matters, as highlighted by the study by Molina Martínez on the anticlerical literature of the nineteenth century. In particular, the lack of productive activity of the friars, the secrets and conspiracies of the monasteries, the intrigues of the Jesuits in order to appropriate the wealth of their followers, the desire for power, the obscurantism and the ignorance of priests, their political attitudes opposing liberalism, and the tortures of the Inquisition, were themes developed by many authors of novels or serialized stories with notable popular success. In the most striking case of the late nineteenth century, the fame of the expriest José Ferrándiz was due to a skilful combination of criticisms of ecclesiastic celibacy with attacks on the interpretation of the dogmas and the perversion of the primitive practices of the Church, of the power of the hierarchy and the reactionary tendencies of the high clergy, and also of the ignorance and lack of spirituality of the low clergy. ${ }^{14}$ In the

I2. "Contribución al Folk-Lore de Asturias", pp. 305-306.

I3. Cantos populares españoles, IV, p. 366. An analysis of attitudes toward the clergy, which confirms the thesis of Rodríguez Marín, in Burke, La cultura popular, pp. 227-229.

I4. On the work of José Ferrándiz, see Molina Martínez, Anticlericalismo y literatura, pp. 295345 . 
twentieth century, when José Nakens, undoubtedly the most popular anticlerical writer of the time, brought together his comments on the vices of the ecclesiastics in several books, the list included in the subtitle of some of these works covered much more than lechery. "Theft, fraud, enticement, exploitation, rape, rape of minors, adultery, abuse, cruelty, brawls, murder, infanticide, homicide, parricide, etc., etc.". Is

For the sexual theme to become the central focus of some interpretations, relegating the other criticisms to the background, it was necessary to incorporate into the analysis an element which does not appear at first sight in the testimonies of traditional culture, or in many of the anticlerical texts of the nineteenth and twentieth centuries. I refer to the rejection by laymen and women of the sexual repression imposed by the Church, a repression which made the sexual activity attributed to the priests themselves all the more intolerable. This was pointed out in I97I by Pierre Conard, in what is probably the first article with this argument. In his search for the "deep roots" of anticlericalism, and of its outbreak at the beginning of the twentieth century, Conard referred to the sexual repression promulgated by priests, whose victims were adolescents subjected to confession and to feelings of guilt. The hostility caused by the submissive relationship of penitents - an occasionally unconscious and repressed hostility - resulted, in his opinion, in the demystification of the clergy, and in particular in a reversal of the virtues which were normally attributed to its members (goodness, poverty and chastity), in order to convert them into their opposites (sadism, lechery, voluptuousness). This same hostility, at a time of crisis between the Church and the state, led to an outright, destructive attack on ecclesiastics. ${ }^{16}$

Although it is true that many middle-class adolescents attended religious schools, and suffered therein the experiences described by Conard, this explanation fails to demonstrate that it was precisely those who underwent these experiences who were subsequently the protagonists of the acts of protest, or at least of the campaigns of propaganda against the clergy. Perhaps for this reason, the explanation of the same subject given by Álvarez Junco emphasizes another, more directly visible, aspect of the rejection of clerical sexuality. As the chastity demanded from the clergy is somewhat "antinatural", the aberrant behaviour - such as the seduction of children by the friars entrusted with their education - or at least the sexual excesses attributed to priests, arose almost inevitably from

I 5. In I9I5 and I916 José Nakens published a series of four books with similar titles, and with the same subtitle: Calumnias al clero (Madrid, I9I5), Más calumnias al clero (Madrid, I9I 5 ), Otras calumnias al clero (Madrid, 1916), Nuevas calumnias al clero (Madrid, 1916). He, moreover, announced the publication of a fifth book, Calumniadores del clero anteriores a José Nakens, with texts of "Holy Fathers of the Church and some eminent Catholic men in science and virtue", but it does not appear to have been published.

16. Conard, "Sexualité et anticlericalisme", pp. 103-I3 I. 
this demand. There were thus two aspects to the anticlerical response: on the one hand, it was a puritan reaction, like the "basic Christian puritanism" which was also present in the attacks on clerical enrichment, but it also reflected the masculine attitudes of "envy toward the great male dominating the female community", and of rebellion against the control of women's privacy by the clergy. ${ }^{17}$

In any case it was Timothy Mitchell, in his latest work, Betrayal of the Innocents, who took this relationship between anticlericalism and sexuality the furthest. Starting from an approach closer to psychoanalysis and social psychology than to history, in this study sexuality has become the key to interpret not just the behaviour of the clergy and of its enemies, but also the whole history of Spain. The historical evolution of Spain was somehow foreshadowed by the fact that the Council of Elvira, in the year 300 , imposed celibacy on the clergy, I 50 years before this became compulsory in the rest of the Empire. Centuries later, the demands of the Council of Trent aggravated the problem: on abolishing concubinage, it prepared the ground for other vices - such as soliciting in the confessional box - and, as a response, for the first expressions of popular anticlericalism, which with time continued to increase. ${ }^{18}$

From the beginning of the nineteenth century, the conflictive relationship with sexuality which apparently led to anticlericalism was closely linked to the pressures placed on the future protagonists of the conflict by pious, frustrated, and overprotective mothers. In some cases this was because they instilled a religious vocation and contempt for other women into their sons which, together with the practices of the seminaries, prevented the normal psychosexual development of future priests. In others it was because, in order to free themselves from this protection, many youths ended up rejecting female piety and becoming enemies of the Church and of the clergy. "The anticlerical counterdiscourse involved a struggle to disidentify not only from the mother, but also from the mother's religious beliefs". Even the laicist legislation of the Second Republic was closely related to the liberation from "Oedipal fantasy" by Azaña and by the other laicist republicans. ${ }^{19}$ More generally speaking, the first third of the twentieth century witnessed a confrontation between the supporters of sexual freedom, and a clergy willing to defend the survival of traditional authoritarian sexuality by all means possible. The culmination of this struggle, the Civil War, could thus be seen as the result of the convergence of the well-off's fear of working-class demands and the bishops' fear of sexual liberation. This convergence, after the military

17. Álvarez Junco, "El anticlericalismo", p. 300; idem, El Emperador del Paralelo, pp. $402-403$.

18. Mitchell, Betrayal of the Innocents, pp. 5, 10-16.

19. Ibid., pp. 43,75 . 
triumph and the establishment of the Franco regime, finally led to the full re-establishment of authoritarian sexuality and political repression.

If we take into account the psychoanalytical inspiration of these arguments, we should not be surprised - although this is highly debatable - that sexuality, and in particular child sexuality, has become the main factor to explain anticlericalism, and even the whole of Spanish history. This is the ambitious objective of a book that the author defines as "the first book to assess the long-term consequences of clergy sexual activity for an entire culture".

What is, however, surprising, is the abrupt ending of the report, an ending in which it is somehow concealed that in recent decades the same path has not been followed. Indeed, after a long period with the triumph of authoritarian sexuality, but also with the continuation of sexual abuse by the clergy (as demonstrated by certain details included in this book), an anticlerical outbreak similar to those which took place at various times in the past has not occurred. This does not square with the central argument of Mitchell, above all if we take into account that the mothers of the sixties and seventies were no more permissive than those of the first third of the century, and so the laymen born under Franco were subject to the same influences as their predecessors.

\section{ANTHROPOLOGY AND HISTORY: THE SEARCH FOR A THEORY}

Over the last two decades, the criticisms of the scant attention paid to the anticlerical movement and the formulation of new explanations did not just come from historians. Starting at the beginning of the eighties, certain anthropologists also complained about the subject being abandoned, while elaborating their own interpretations. Like historians, anthropologists were also right to criticize. It is true that at the beginning of the decade the anthropologist Julio Caro Baroja wrote a synthesis of the evolution of anticlerical trends in contemporary Spain, but in this case his work responded more to approaches of cultural history that to anthropology in the strict sense. ${ }^{20}$ On the other hand, research by Anglo-Saxon and Spanish anthropologists, starting with the pioneering study by Julian Pitt-Rivers, The People of the Sierra (1954), had almost completely abandoned the analysis of the opposition to the Church and Catholicism, while paying more attention to the intense Catholic piety and the rich tradition of ritual devotions in the areas studied. ${ }^{2 \mathrm{I}}$ This lack of interest in anticlericalism was

20. Caro Baroja, Introducción a una Historia Contemporánea.

2 I. In the Preface to the second edition (197I), Pitt-Rivers indicated that the political conditions of Franco's Spain prevented him from including in his study the materials that he had collected on religion and anarchism. I quote from the Spanish translation: Un pueblo de la sierra, pp. $30-3 \mathrm{I}$. 
probably due, as David Gilmore pointed out, to the priority granted by Anglo-Saxon anthropology to factors of social cohesion, and to the correlative omission or underestimation of the conflicts. In the eyes of these scholars, religious practices, usually associated with women, thus became the rule of community behaviour, while male dissidence appeared to be an anomaly of scarce importance, to which the researcher did not pay particular attention. ${ }^{22}$

Only a few studies on anarchism paid attention to the religious components of this tendency and to its opposition to the established Church, thus linking up with the descriptions of the anarchist millenarianism that Brenan had spread in the Anglo-Saxon world. ${ }^{23}$ The new contributions by anthropologists did not come from there, however, but from the works, which appeared precisely at the beginning of the I980s, by David Gilmore and Bruce Lincoln. ${ }^{24}$ These two texts are very different, both as regards their themes and their methods, although their conclusions can be considered to be complementary. The study by Gilmore was the result of fieldwork in an Andalusian village, which the author called "Fuenmayor", at the beginning of the seventies. For his part, the study by Lincoln was devoted to analysing, from documentary sources, the most "horrific" form of anticlerical violence, the exhumation and public exhibition of the corpses of many ecclesiastics during the Civil War. Despite these differences, both approaches have some common characteristics, of particular interest here being the importance that both grant to the political and social components of the anticlerical conflict.

Gilmore recognized that the most frequent criticisms of the Andalusian working class regarded the sexual behaviour of the clergy. However, these attacks really demonstrated a rejection of the political and social position of the Church, whose links with the rich and powerful had converted it, in the opinion of the proletariat of the area, into the "spiritual branch of coercion". Similarly, according to Bruce Lincoln, although the anticlericals of the thirties attacked the wealth of the Church with great insistence, "it was less the possessions of the Church which gave rise to violent anticlericalism than its consistent service to the interest of the wealthy". Since the beginning of the nineteenth century, Spanish Catholicism had represented a typical case of a "religion of the status quo". Evidence of this was the defence by the hierarchy and the clergy of the political and social order in force, from the privileged position granted

22. Gilmore, "The Anticlericalism of the Andalusian Rural Proletarians", pp. $478-483$.

23. Brenan, The Spanish Labyrinth; a recent examination of the theses of Brenan, in Castro Alfín, "Anarquismo y protestantismo", pp. 197-220. And an example of these anthropological analyses, in Mintz, Anarchist of Casas Viejas, in particular pp. I-9, 63-76.

24. Gilmore, People of the Plain; idem, "Anticlericalism of the Andalusian Rural Proletarians"; Lincoln, "Revolutionary Exhumations”. 


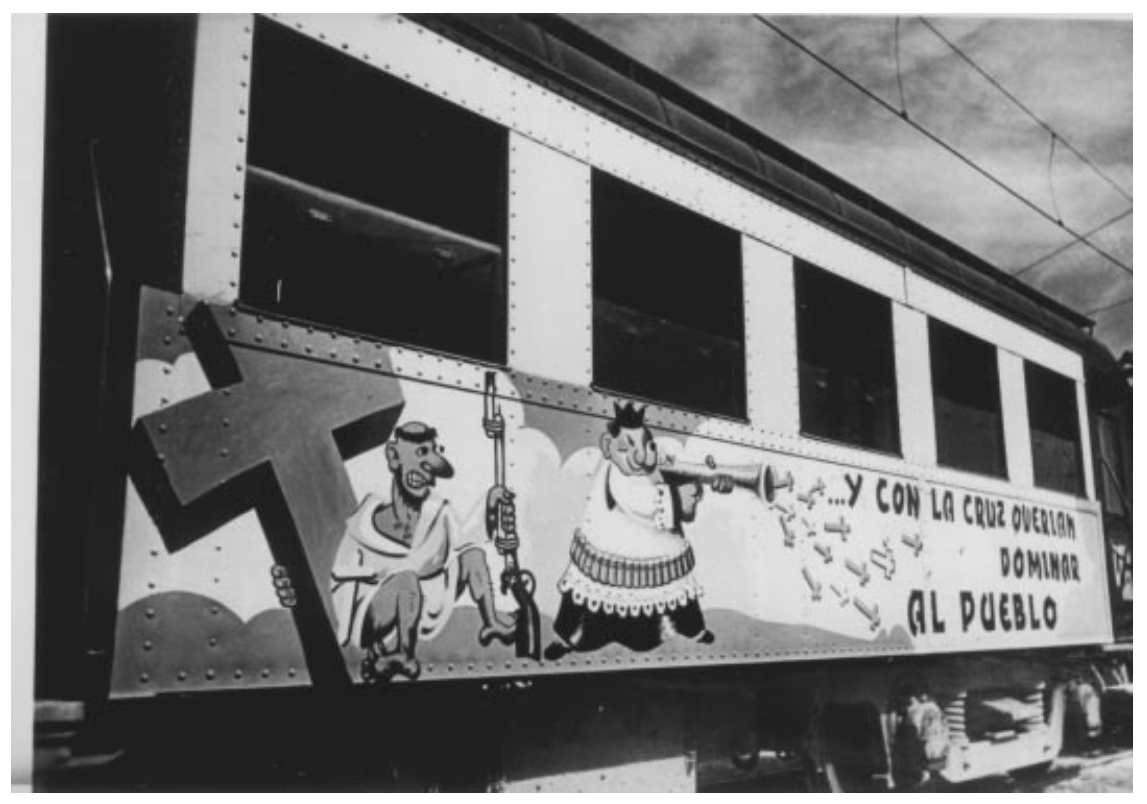

Figure 3. "The Sindicato de Dibujantes y Pintores (the union of draftsmen and painters) from Barcelona has formed teams, which decorate trains with splendid inscriptions and antifascist allegories". The slogan on the train reads: "and with the Cross they wanted to control the people".

CNT Collection, International Institute of Social History, Amsterdam

to it by being the official state religion. However, after the re-establishment of the Republic and the loss of a good number of the ecclesiastic privileges, the Church started to promote a "religion of the counterrevolution", associated with the parties which were trying to alter or to liquidate the republican regime. This resulted in a violent popular reaction against it in the areas where the military rebellion of July 1936 did not triumph. This reaction should not be seen as an attack on religious ideas (as stated by the Spanish bishops in a collective pastoral letter of July 1937), but rather as an assault on "one specific religious institution, an institution closely aligned with the traditionally wealthy and powerful”. ${ }^{25}$

However, these analyses of anticlerical feelings and actions were not accepted by all anthropologists. Indeed, at the end of the I980s, Manuel Delgado set out his criticism and elaborated a new proposal, what he called a "culturally orientated theory of contemporary Spanish anticlericalism". This theory obviously supported a rejection of the traditional view of the irrationality of the "depraved, bloodthirsty masses" as an explanation of

25. Lincoln, "Revolutionary Exhumations", pp. 247-248, 260. 
the violence against the clergy, but at the same time it differed from the approaches that I have just summarized, putting the emphasis - directly linked to Levi-Strauss's approach - on the unconscious categories, instead of on the conscious, visible categories. ${ }^{26}$ The alternative formulations of this author, which, as far as we are concerned, can be summarized in three basic theses, arise from this difference.

First thesis: anticlericalism was a religious phenomenon, not the byproduct of other confrontations. The keys to explain it cannot therefore be found in a Church linked to the economic, social or political power, but rather in the holy sphere. In more radical terms, "in Spain, like it or not, the temples were burned because they were temples, and the priests were shot for being priests". ${ }^{27}$ The anticlerical acts were always therefore clearly counter-rituals, authentic theatrical productions inspired by the religious ritual itself. The abundance and repetition of these counter-rituals is explained - in the second thesis - by the influence of the traditional religious culture, and also by the high degree of ritual violence of Spanish popular culture (reflected, for example, in the treatment of various animals in the traditional festivities of the country). The "strong ritual pressure" and the "difficult to support psychological tension" arising from it were precisely the causes of the popular rebelliousness, which can be seen both in the blasphemy and the scatological allusions to holy things, common in day-to-day life, and in the sacrophobic violence at the times of greater confrontation. ${ }^{28}$ The fact that these reactions were especially intense among men is linked to the fact that in Spain the ecclesiastic sphere has been a sort of "liberated female zone", and therefore the violence was presented as an "exorcism or defusing of antimale threats" and, at the same time, as the "reconquest of redoubts from where the female exerted a supposed power". ${ }^{29}$

As it was found in cultural structures with a high degree of permanence, this mainly male anticlericalism should be defined as a "long-lasting phenomenon", and not as the pure result of specific moments of historical situations (third thesis). In particular, the Spanish anticlerical movements of the nineteenth and twentieth centuries are closely related to similar movements from preceding periods, both in Spain and abroad, such as, for example, the religious risings of the period of the Protestant Reformation. In the final analysis, the destructive work of all of them was a response to the need to put an end to the symbolic system of traditional societies, to which the Church lent its ideological and bureaucratic apparatus, in order

26. An explanation of his method, and of the differences indicated in the text, in Delgado Ruiz, "La antirreligiosidad popular en España", pp. 499-5 I4. Also in Delgado, Las palabras de otro hombre, pp. II $-\mathrm{I} 9$.

27. Idem, La ira sagrada, p. 5 I.

28. Ibid., pp. 7I-79.

29. Idem, Las palabras de otro hombre, p. 34. 
to give way to a modern, middle-class, secularized and individualist society. With the high degree of violence as its only distinguishing feature, the Spanish version of the "antiritualistic and antisacramental impulse which characterizes in the last centuries the gradual arrival of modern Reason" consequently served the same objectives as the other versions of the same impulse, that is to say that it "objectively" benefited the middle class, for which the Church was no longer a bastion or a support, but rather an obstacle on the path to secularization..$^{\circ}$

It is obvious, according to Delgado, that it is difficult for historians more attentive to what appears at first sight than to the "veiled sense" or to the "non-explicit reason" of events - to access this "culturally orientated theory", whose development should be left to anthropologists. Despite this, and although it may appear to be contradictory, his theses are based on an original interpretation of the previous formulations of historians such as Álvarez Junco and Ranzato. ${ }^{31}$ It is even more surprising that it is professional historians who have been the most influenced by Delgado's analysis - either using it to support their arguments, in particular as regards its insistence on the religious causes of anticlericalism, ${ }^{32}$ or criticizing it, above all criticizing the definition of this movement as a long-lasting phenomenon.

Let us start by looking at this last criticism. As Demetrio Castro indicated, with this reference to its long duration a substantial difference between contemporary anticlericalism and the previous protests is forgotten. While, since the late Middle Ages, attacks on the clergy had been demonstrated through sayings, songs, and jokes, in the nineteenth and twentieth centuries the hostility led to increasingly intense violent acts, from the murders of 100 members of the clergy in I $820-1823$ to the almost 7,000 priests, monks and nuns who suffered the same fate in 19361939. Insofar as the time variable is not immaterial when it comes to analysing the anti-ecclesiastic protests, it would therefore be necessary to talk about "rupture or metamorphosis" rather than continuity. This statement, seen from the point of view of professional differences, could be interpreted as the response of the diachronic view of the historian, as opposed to the synchronous character of the anthropological analysis. ${ }^{33}$

There are, however, other criticisms. Although the anticlerical actions can be defined as counter-rituals, there would not appear to be a direct relationship between these protests and the pressure of religious rituals. An

30. Idem, "Anticlericalismo, espacio y poder", pp. $162-163,176-178$.

3I. In addition to the studies of Álvarez Junco, already mentioned, Delgado refers to Ranzato, "Dies Irae", pp. 59-72, and to the polemic to which it gave rise in the following numbers of this journal.

32. See, for example, the analysis of religious persecution during the Civil War (inspired among others by Ranzato and Delgado) by de la Cueva, "Religious Persecution", pp. 355-369.

33. Castro Alfín, "Cultura, política y cultura política”, pp. 87-97. 
almost common-sense observation, which is, however, strengthened by all the details available on religious practices and anticlerical attitudes in contemporary Spain, opposes this relationship. While the sectors closer to the Church normally belonged to the better-off classes and did not participate in these disturbances, those who murdered, destroyed, parodied, or ill-treated were those who observed the religious duties the least, and therefore those who should feel the least oppressed. ${ }^{34}$

The view of the change from a traditional to a modern society, and of the role of the anticlerical movements in this process, is even more debatable. Even in accepting that they are ideal models or types, it is difficult to reconcile historical details with this interpretation. Many of the harshest criticisms of the Church and the clergy in contemporary Spain refer to their close links with the powerful and to their steadfast defence of the established social order, in which the middle classes played an increasingly important role. On the contrary, Delgado's interpretation obliges him to confront the middle class with the ecclesiastic institution, as only thus can he make the former the protagonist, and the latter the antagonist, in the movement from the old to the new model of society, that is from "an organization based on inherited, objectifiable positions, the traditional one", in which the Church performed basic functions, to another, the modern middle-class one, "founded on personal and voluntary agreement, and for which subjectification was the main requirement". ${ }^{35}$

\section{RETURN TO HISTORY: IDEAS, PROPOSALS AND MOBILIZATIONS}

With a background formed by these interpretations, in the I990s the interest in the past of the anticlerical movement - curiously coinciding with the disappearance of the movement from the social life of modernday Spain - has given rise to a proliferation of historical research which has, to a certain extent, mitigated the previous deficiencies. As is common in the most recent Spanish historiography, these were initially studies on regions or towns in restricted time periods: in particular, on Málaga, Santander, and Aragón at the end of the nineteenth and in the initial

\footnotetext{
34. On religious practices in the nineteenth century, see Callahan, Iglesia, poder y sociedad, pp. 235-240. For the twentieth century, Lannon, Privilegio, persecución y profecía, pp. 25-35. The fact that in some areas of the country the anticlerical protests coincided with the Catholic mobilizations, in particular in the first decade of the twentieth century (as shown by the maps included in Gallego, "Sobre las formas de pensar", pp. 300-307), does not at all imply that the protagonists of both were the same or that they were driven by the same impulses.

35. Delgado, "Anticlericalismo, espacio y poder", p. I63.
} 
decades of the twentieth century. ${ }^{36}$ The first synthesized works then appeared, as a result of the collaboration of different researchers, such as the volumes directed by Rafael Cruz (El anticlericalismo, 1997) and by Emilio La Parra and Manuel Suárez Cortina (El anticlericalismo español contemporáneo, 1998). Thanks to these publications, not only do we have a better knowledge of the origins, development and decline of the anticlerical movement during the nineteenth and twentieth centuries, but also our capacity to contrast the causal analyses offered by other disciplines, and included in the preceding pages, with precise historical data, has increased.

What stands out above all in these studies is the importance of the political causes when it comes to explaining contemporary Spanish anticlericalism. This importance is not always explicitly highlighted by the authors mentioned, but can be deduced from their meticulous accounts, and is expressed on at least three different levels. Firstly, it is reflected in the consideration of the political and social power of the Catholic Church, and of its links with the currents of opinion at odds with the new liberal order, as a fundamental factor in understanding the anticlerical protests. It is also revealed in the examination of political objectives, of a liberal or republican nature, defended by the organizations which were most opposed to the clergy and, finally, in the close relationship between the political crises and the outbreaks of anticlericalism. From all of this it can be deduced that, when it comes to seeking an overall explanation, the main interpretative keys can be found in the field of the struggle for power, rather than at the other levels previously explored by historians or anthropologists.

The political struggle between a Church which defended the old regime and the new liberal trends, at a time when the traditional order was starting to be in crisis, was already responsible for the anticlerical outbursts of the first third of the nineteenth century. It is true, as Emilio La Parra indicates, that the roots of anticlericalism can be found in the criticisms of the enlightened thinkers of the eighteenth century, aimed in particular at the regular clergy, whose behaviour even then was not considered to be in keeping with the official doctrine of the Church. ${ }^{37}$ The jump to violence was not, however, just the result of the attacks of enlightened thinkers or liberals, but rather arose from an accumulation of events which somehow foreshadowed subsequent actions. In particular, its roots can be found in the rejection by a wide sector of the clergy of the first reformist measures of the Cortes of Cádiz (such as the abolition of the Inquisition, in I8 I3)

36. Mateo, Anticlericalismo en Málaga; de la Cueva Merino, Clericales y anticlericales; Salomón Chéliz, "La crítica moral al orden social”, (unpublished doctoral thesis, Zaragoza, I996); idem, "Republicanismo y rivalidad", pp. 2 I I-229.

37. La Parra López, "Los inicios del anticlericalismo", pp. 17-64. 
and in the subsequent opposition to the new rules of the Trienio Liberal (I 820-I 823) which affected, above all, the regular clergy. At that time only a minority of the clergy supported the constitutional regime, while the majority approved of, and even participated directly - at times in a noteworthy fashion - in the absolutist uprising of 1822 . The anticlerical violence, which claimed almost Ioo victims in I $822-1823$ and first revealed the traits of cruelty and viciousness which with time would become common, can therefore be considered as a "[liberal] rebuttal of the absolutist insurrection"..$^{8}$

Something similar occurred in the following wave of violent anticlericalism, in I 834-I 835. In this new situation of political crisis, after the death of Ferdinand VII, the Church granted the pretender, Don Carlos, the ideological coverage that he needed. Moreover, in the initial months of I 834, numerous friars joined the Carlist uprising or donated considerable funds for the troops of the pretender. The fact that the immediate reasons for the outbreaks of violence appear to be banal (for example, the rumour spread throughout Madrid, in July I 834, that the friars had poisoned the public fountains) should not make us forget that these explosions of violence took place at a time when - as Larra explained in one of his articles - the Spanish people saw "the monasteries as sources of this war [and] friars as enemies". 39

After this second outburst of violence, with over I 40 monks murdered, the absence of similar explosions for the rest of the century attracts our attention. This did not at all mean that the clerical question was forgotten. Indeed, during the times of progressive predominance or in the revolutionary periods, the struggle against ecclesiastic power was always in the foreground. Laicist, and even anticlerical, measures were approved at this time, from the regulations on the sale of ecclesiastic goods and the closure of monasteries in the thirties, to the establishment of the freedom of cults in the 1869 Constitution, and even the attempted separation of the Church and the state and the proposals for the complete secularization of civil life included in the draft constitution of the federal republic, in I873. At the same time, the republican publications increasingly insisted on considering the clergy as the main obstacle to the new democratic ideas. Despite this, the violent incidents were isolated and exceptional. Even the Catholic press only referred to a few sacrilegious thefts, irreverent treatment of images and humiliation of clerics during the Sexenio Revolucionario (I868-i 874).

The contrast with what occurred in earlier times is, therefore, very significant. If, in the I 820 s and I 830 s, the violence was much more intense

38. Pérez Garzón, "Curas y liberales”, p. 77.

39. The events of $1834-1835$, in Moliner Prada, "Anticlericalismo y revolución liberal", pp. 69-95. 
than in the rest of the century, despite the fact that with the passing of time religion had been declining in wide areas of the country, it has to be concluded that loss of faith and the influence of lay intellectuals were not responsible for the anticlerical outbursts or, what amounts to the same, there was no causal link, whatever the ecclesiastic historians say, between the "apostasy of the masses" and the violence against the clergy. It should rather be understood that the violent actions were a response to the clerical threats to the liberal order, and that this response was unnecessary in periods of progressive predominance or in revolutionary times, when the government could present reforms which limited the power of the Church.

In any case, the situation underwent a substantial change with the Cánovas Restoration. This was not just because the 1876 Constitution granted the Catholic Church clear primacy, in comparison with the other religious confessions, but also, and above all, because the Church took advantage of this situation to try to recover the political and social predominance lost over the previous half century. Despite this, during the final decades of the nineteenth century, there was still a period of "relative calm" in which the displays of anticlericalism "did not go beyond the printed paper of the democratic bodies or of the modest tribunes of republican premises". $4^{\circ}$ Indeed, the proposals for secularization of the state, in the more moderate formulations, or of the state and society, in the more radical ones, were a substantial component of republican ideology, circulated with great energy by certain distinguished adherents of this current of opinion. The criticisms of the Church and of its members were therefore of a predominantly political nature, as revealed, among others, by José Nakens, editor of the anticlerical newspaper par excellence, El Motin. It is true, he admitted in an autobiographical text, that most of his attacks reproduced the classical criticisms of the vices of the clergy, in particular their sexual behaviour and their love of wealth (although on other occasions he also covered more modern themes, such as clerical obscurantism and ecclesiastic opposition to reason and progress). However, what he was really interested in was "undermining the authority of the clergy", for a fundamentally political reason, "because I saw and I see in the clergy (and even more so in friars) the logical incarnation of absolutism", that is to say because priests continued to be the firmest supporters of Carlism and therefore the greatest threat to the freedom of Spaniards. ${ }^{\mathrm{I}}$

Once again the step from criticisms in the press and in republican speeches to actions against the clergy was linked to a political crisis. The Cuban War (1895-1898) and the awareness that the Church played a

40. The first citation, in Suárez Cortina, "Anticlericalismo, religión y política", p. I07.

4I. Nakens, "Inmodestia", pp. 27-28. An analysis of the ideas of Nakens, in Pérez Ledesma, "José Nakens (I84I-I926)", pp. 299-328. 
decisive role in the conflict, and was willing to continue to do so in Spanish political and social life after the defeat, were necessary for new mass mobilizations to occur, these being frequent in the years I $899-190 \mathrm{I} .4^{2}$ The anti-ecclesiastic protests spread throughout the country from then until the eve of the First World War, while liberal governments tried to curb the growth of the religious congregations. An essential new development during this stage was the extension of modern forms of organization and collective action (riots, conferences, meetings or demonstrations, and even boycotts of religious acts and celebrations), which obviously tried to influence the political agenda and to counter the mobilization of the Catholics in defence of ecclesiastic privileges. ${ }^{43}$

The proposed reforms failed again, however, and clerical power was strengthened by the return of the conservatives to government in 1907 . The Tragic Week (1909), a new version of the traditional anticlerical riot, took place within this context, aggravated by the outbreak of the Moroccan war, although on this occasion the burning of religious buildings replaced the nineteenth-century practice of killing friars. Once again, the political circumstances played a decisive role in the resurgence of the violence, not just as regards the origins of the protest (a reaction against sending reservists to fight in Morocco), but also because the violent acts occurred at a time of intense political debate on the role of the Church, and to a certain extent were linked with the failure of reformist projects of the previous years. ${ }^{44}$

As in the nineteenth century, what is surprising is the abrupt conclusion of this wave of protest. Starting from I9I 3 , the anticlerical organizations disappeared, the tone of confrontation diminished, and the religious question was practically removed from public debate. This can be explained, according to Julio de la Cueva, by the inability of the anticlerical movement to "fully establish itself as a social movement". That is to say, that it is related to the fact that the anticlerical organizations and protests had until then been in the service of a "populist mobilization strategy" promoted by the republicans, and abandoned by the latter when they lost their immediate relevance. ${ }^{45}$ The decline is, however, also related to the failure of the previous mobilizations, and even to the abandonment of proposed reforms by the liberal party, which until then had been the main ally of the anticlerical movement inside the establishment. The political power confirmed this failure with the solemn act of dedication of Spain to the Sacred Heart of Jesus in I919.

42. On these mobilizations, see Pérez Ledesma, "La sociedad española", pp. I34-I43.

43. For the clerical actions of that decade, see de la Cueva, "Cultura y movilización", pp. I69192; and idem, "Católicos en la calle", pp. 55-79.

44. This interpretation is expanded on in Pérez Ledesma, "El Estado y la movilización social", pp. 228-23I.

45. De la Cueva, "Movilización política”, pp. I24-125. 


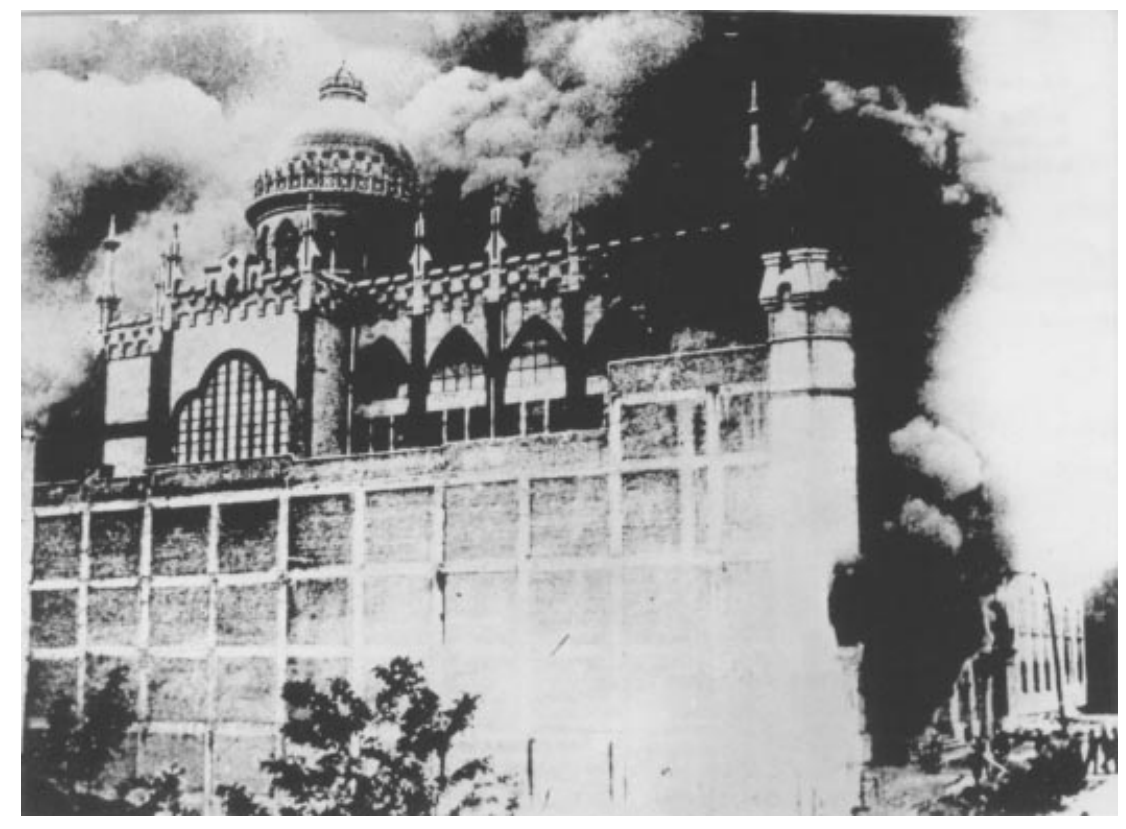

Figure 4. Picture postcard of a Carmelite monastery set on fire, Madrid, I936. International Institute of Social History, Amsterdam

Decline did not, in any case, mean oblivion. Despite their defeat, anticlerical attitudes did not immediately disappear; they simply awaited a new political opportunity to be reactivated. The opportunity arrived after the establishment of the Second Republic, the immediate reaction being the burning of 100 monasteries in the same month of May I93 I. Again, the immediate cause of the outbreak - in the case of Madrid, a reaction against the provocations of the founders of an Independent Monarchist Circle should not conceal the fact that these fires reflected the malaise of certain radical sectors in the face of the close links of the Church to the former monarchist regime. The malaise broke out again violently, once again coinciding with situations of political crisis, on a further two occasions during the republican period: during the October revolution in Asturias, when thirty-four ecclesiastics were murdered and almost sixty religious buildings burned, and after the triumph of the Popular Front, when over ıo० religious buildings were completely or partly destroyed by fire (although no members of the clergy were victims of the violence in the months prior to the war). ${ }^{4}$ 
It was above all in the weeks after the military uprising of 18 July that the anticlerical violence reached its peak. Approximately half of the almost 7,000 members of the clergy murdered during the Civil War died in the last few days of July and during the month of August. According to recent analyses, rather than political reprisals in this case, we should talk about genuine "religious persecution". Religious, not political, as it was not in response to the Catholic Church's support of the "nationalist" side, but rather preceded any ecclesiastic declaration in this respect. It was also religious because, in addition to the indiscriminate murder of members of the clergy, often accompanied by torture and humiliation, the sacrophobic actions were directed against anything related to the Church and its beliefs - temples and monasteries, holy images and liturgical objects, ecclesiastic festivities and even the religious names of streets or towns. Finally, it was religious because the ultimate aim of those who unleashed it was to put an end to all remains of the Catholic religion in the new revolutionary, lay society. 47

What is debatable in this characterization, however, is the radical separation between the political and the religious terrain. In the preceding years, the Church had been an extremely important political figure, radically confronted with the laicist legislation of the first two years of the Second Republic, and in general with the republican system. Furthermore, the social fracture between believers and nonbelievers coincided to a large extent with the political fracture between supporters and enemies of the republican regime. An explicit declaration in favour of the rebellious soldiers was not, therefore, necessary for the Church to be identified, from the very beginning of the war, with the uprising. Anticlerical and even antireligious feelings were thus reactivated by the situation of war and by the attribution of not just religious, but also political culpability, to the ecclesiastic institution and to its members (at times, starting from rumours about the possession of arms or the attacks of snipers from religious buildings).

The same correlation between politics and religion is found, although in the opposite direction, in the period of the transition to democracy. As Rafael Cruz has pointed out, in addition to the structural transformation of Spanish society, starting above all in the sixties, and to the changes in the Catholic Church after Vatican Council II, the joint mobilizations of Catholics and non-Catholics against the Franco regime, and what this experience meant for the cultural perception by laymen and women of the role of the Church and its ministers, were instrumental in the disappearance of anticlericalism. After experiencing "a dynamics of alliances, of mutual aid" between anti-Franco Catholics and non-Catholics, the old

47. In addition to the texts by Delgado and Ranzato, already cited, see a summary of these theses in ibid., pp. 259-285. 


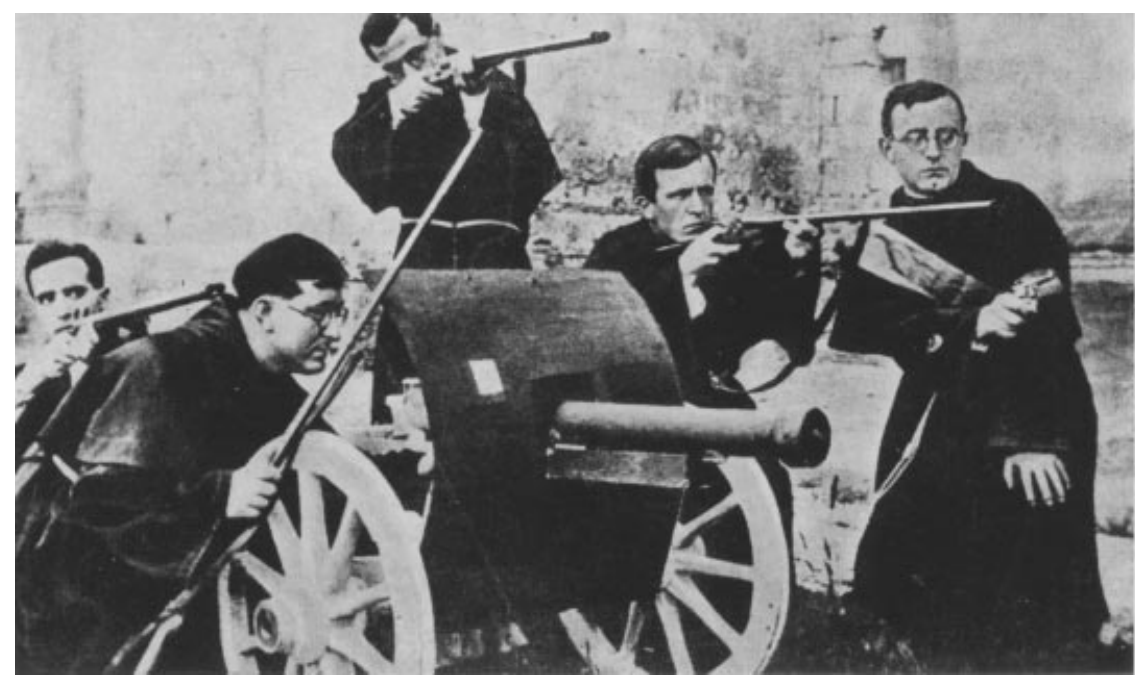

Figure 5. "The 'representatives of God on earth' also take up the arms. In a Catalan village these priests turn against the people." This photograph, published in Solidaridad Obrera, I August 1936, by the Comissariat de Propaganda of the Generalitat de Catalunya, was allegedly found in Count Vallellano's house, but probably originates from before 1936.

International Institute of Social History, Amsterdam

political culture which had sustained anticlericalism collapsed, and the anti-ecclesiastic mobilizations lost all meaning..$^{8}$

Does this represent a definitive crisis for anticlerical attitudes? Yes, in the opinion of most analyses which, starting with the surveys of the eighties, accept that the place formerly occupied by anticlerical attitudes is now covered by simple religious disaffection. However, a different reading of the same surveys - in particular of the criticisms by many of those polled of the wealth of the Church and of its links with the powerful - has led Alfonso Botti and Nieves Montesinos to defend the hypothesis that "at least one in three Spaniards expresses and maintains attitudes which could be included within the sphere of anticlericalism". ${ }^{49}$ They may be right with this reading, but it is in any case obvious that these attitudes have not yet been reflected in collective action.

\section{ANTICLERICALISM: A POLITICAL MOVEMENT}

As some of the best-known experts in the analysis of collective action have pointed out, political opportunities are decisive for the appearance and 


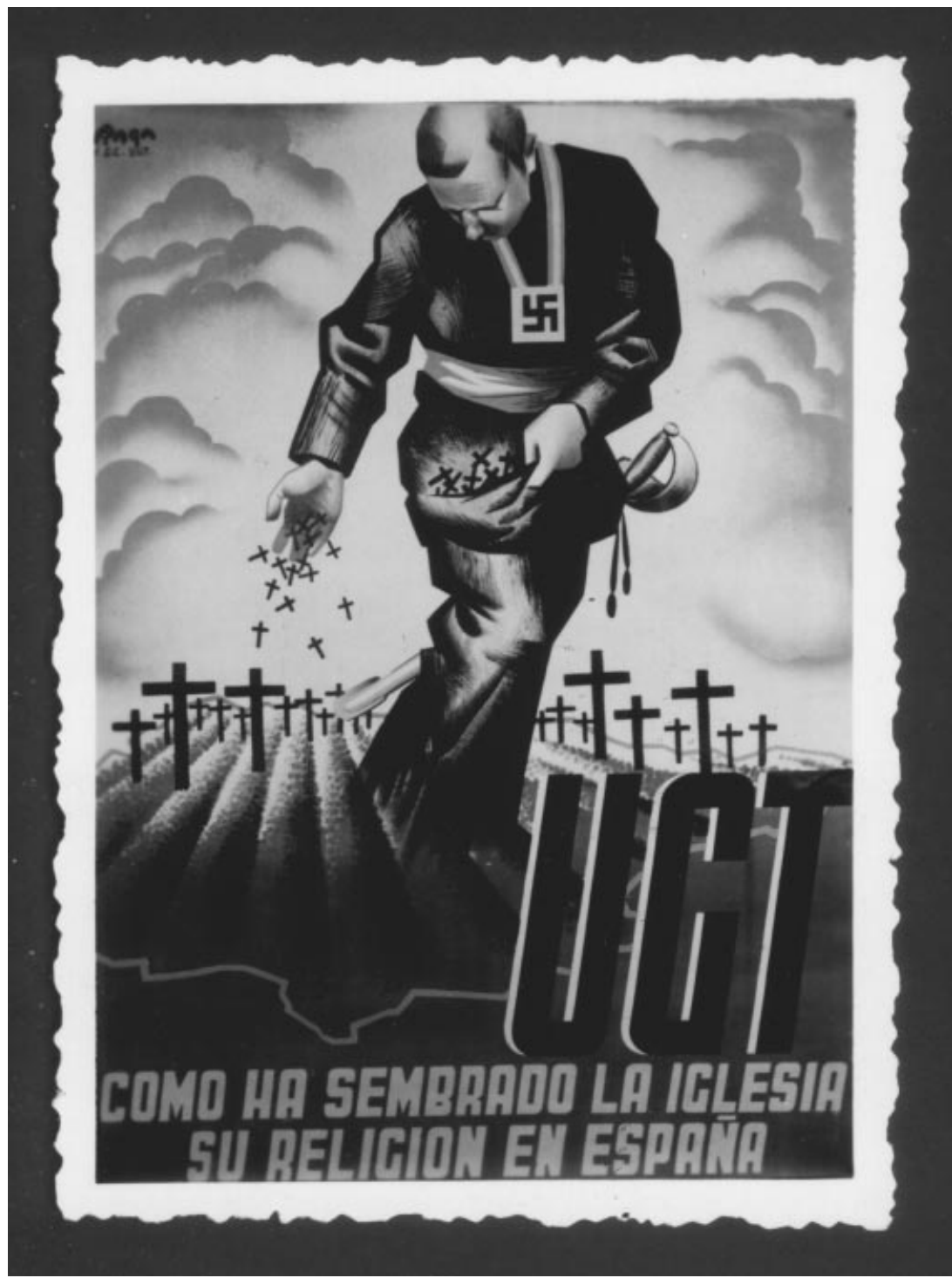

Figure 6. "How the church has sown its religion in Spain"; poster from the Unión General de Trabajadores (UGT), c. 1937, designed by Raga.

International Institute of Social History, Amsterdam

generalization of social movements. ${ }^{\circ}$ Spanish anticlericalism in the nineteenth and twentieth centuries is a perfect example of this thesis. As we have already seen, the anticlerical outbursts took place in situations of 50. See, for example, Tarrow, Power in Movement. 


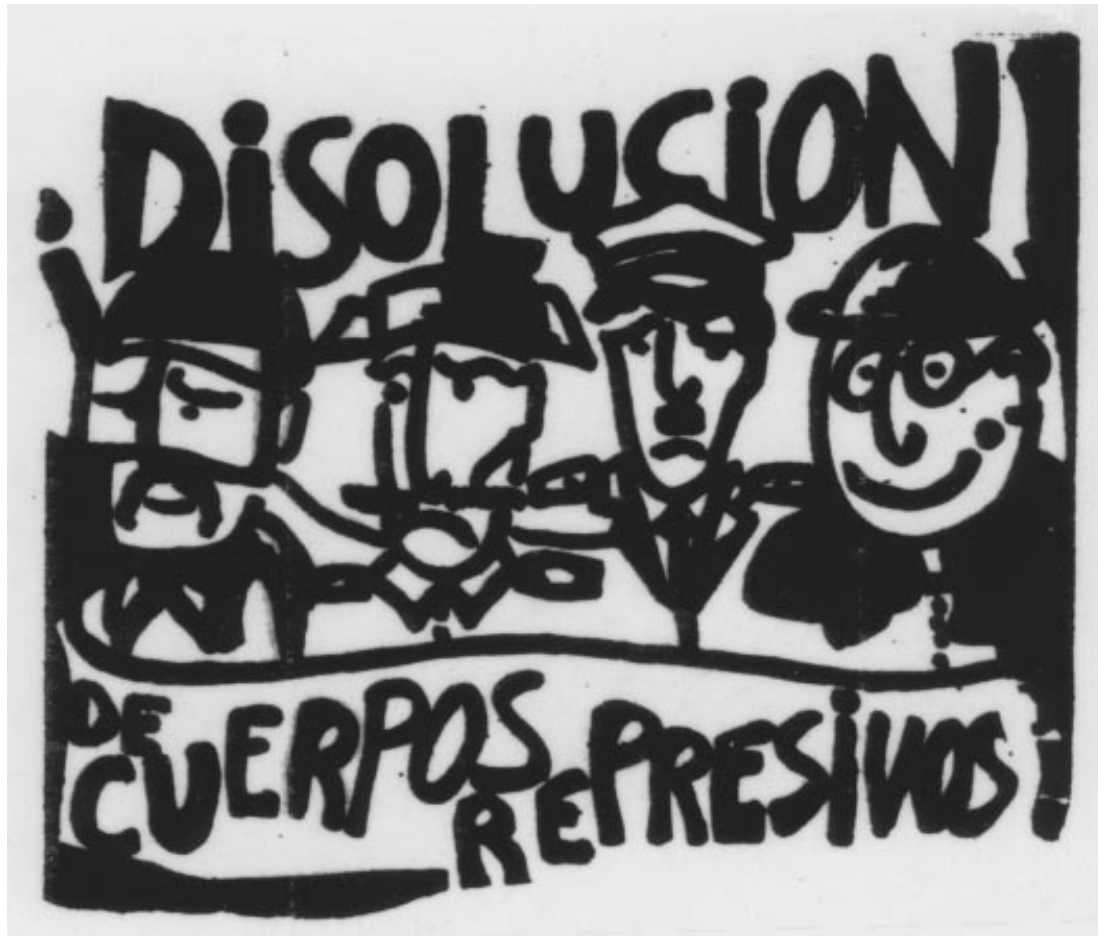

Figure 7. "Dissolution of repressive bodies"; sticker, probably from 1976.

International Institute of Social History, Amsterdam

civil or external war, of revolution or, at least, of radical political change. In these circumstances, the old attitudes of opposition to the clergy that the liberal, republican, or libertarian press and freethinking or anticlerical newspapers had kept alive, were given fresh impetus, and even became integrated in a new cultural framework, a political culture in which violence was considered by the different adversaries to be a legitimate form of action. The violent acts against the clergy which occurred on these occasions, but not outside them, cannot, consequently, be considered as just another reflection of the violent traditions of Spanish culture, comparable with the mistreatment of animals in popular festivities, nor as a simple response to the pressures of religious ritualism or sexual repression. The violence was related more to the consideration of ecclesiastic institutions as enemies of freedom of conscience, this idea having spread during the nineteenth century throughout most European countries except Spain, and, more generally, as enemies of what was 
considered as "progress". ${ }^{\text {I }}$ During times of war, when this violence reached its highest degree of cruelty, it was undoubtedly related to the cruelty which was at the same time wielded against lay people, both by anticlerical sectors and by the members of the clerical side.

In other words, the perception of the Church as a social and political power at odds with new objectives promoted by liberal trends, a view of ecclesiastics as agents of political and ideological reaction, the discriminatory measures against nonbelievers and the failure of attempts at political and social secularization, are factors to be borne in mind when it comes to explaining the success of anticlericalism and the outbreaks of violence which this sometimes provoked. The main difference between contemporary anticlericalism and the former traditions of criticism of the clergy lies in these factors. This is clearly indicated by Demetrio Castro, who said that while the members of the Church were not involved in the political struggles, the hostility against them did not go beyond the threshold of oral or written criticism. However, when the clerical attitudes "materialized in an active, even military participation of some ecclesiastics in the political conflicts of the liberal revolution", or in the power struggles of subsequent periods, "the priests and, consequently, everything linked to them, became objects of harassment and aggression".52

\section{B I B L I O G R A P H Y}

Álvarez Junco, J. "El anticlericalismo en el movimiento obrero", in Jackson, Octubre 1934, pp. 283-300.

Álvarez Junco, J. El Emperador del Paralelo. Lerroux y la demagogia populista (Madrid, I990).

Álvarez Junco, J. La ideología política del anarquismo español (I868-I9I0) (Madrid, 1976)

Álvarez Santaló, C., et al. La religiosidad popular, vol. i, Antropologia e Historia (Barcelona, 1989).

Botti, Alfonso and Montesinos, Nieves "Anticlericalismo y laicidad en la postguerra, la transición y la democracia”, in La Parra López and Suárez Cortina, El anticlericalismo español contemporáneo, pp. 303-370.

Brenan, Gerald The Spanish Labyrinth: An Account of the Social and Political Background of the Civil War (Cambridge, 1950).

Burdiel, I. and Pérez Ledesma, M. (eds) Liberales, agitadores y conspiradores. Biografias heterodoxas del siglo XIX español (Madrid, 2000).

Burke, Peter La cultura popular en la Europa moderna (Madrid, I99I).

5I. For the differences with other European states, see the paper on "Anticlericalismo y Secularización en España", presented by the author of this paper in the Congress "Las claves de la España del siglo XX” (Valencia, October 2000, to be published shortly).

52. Castro Alfín, "Cultura, política y cultura política”, p. 96. 
Callahan, William J. Iglesia, poder y sociedad en España, I750-1874 (Madrid, I989).

Cantos populares españoles. Recogidos, ordenados e ilustrados por Francisco Rodríguez Marín, 5 vols (Madrid, I981; ist edn, Seville, I882).

CÁRCel Ortí, Vicente La persecución religiosa en España durante la Segunda República (1936-1939) (Madrid, I990).

Caro Baroja, J. Introducción a una Historia Contemporánea del Anticlericalismo Español (Madrid, I980).

Castillo, S. and Ortiz de Orruño, J.M. (eds) Estado, protesta y movimientos sociales (Bilbao, I998).

Castro Alfín, D. "Anarquismo y protestantismo. Reflexiones sobre un viejo argumento”, Studia Historica. Historia Contemporánea, I6 (1998), pp. 197-220.

Castro Alfín, D. "Cultura, política y cultura política en la violencia anticlerical”, in Cruz and Pérez Ledesma, Cultura y movilización, pp. 69-97.

Conard, Pierre "Sexualité et anticlericalisme (Madrid, I9Io)", Hispania, i I7 (I97 I), pp. IO3-I3I.

"Contribución al Folk-Lore de Asturias. Folk-Lore de Proaza. Notas y apuntes recogidos y ordenados por L. Giner Arivau”, Biblioteca de las Tradiciones Populares Españolas, vol. 8 (Madrid, i 886).

Cruz, Rafael (ed.) El anticlericalismo (Ayer, 27) (Madrid, I997).

Cruz, RAFAEL “Los estudios sobre anticlericalismo en España al final del milenio”, in Cruz, El anticlericalismo, pp. 219-229.

Cruz, Rafael “'Sofía Loren, sí; Montini, no’. Transformación y crisis del conflicto anticlerical”, in Cruz, El anticlericalismo, pp. i 8I-2 I7.

Cruz, R. and Pérez Ledesma, M. (eds) Cultura y movilización en la España contemporánea (Madrid, I997).

Cueva, J. DE LA “El anticlericalismo en la Segunda República y la Guerra Civil”, in La Parra López and Suárez Cortina, El anticlericalismo español contemporáneo, pp. 2II-3OI.

Cueva, J. DE LA "Católicos en la calle: la movilización de los católicos españoles, I 898-i 923", Historia y Política, 3 (2000), pp. 55-79.

Cueva Merino, J. De la Clericales y anticlericales. El conflicto entre confesionalidady secularización en Cantabria (1875-1923) (Santander, 1994).

Cueva Merino, J. DE LA "La cuestión clerical-anticlerical contemporánea en la historiografía española”, in Rueda, Doce estudios de historiografía contemporánea, pp. I 2 I-I 42.

Cueva, J. DE LA “Movilización política e identidad anticlerical, I898-1910”, in Cruz, El anticlericalismo, pp. IOI-I25.

Cueva, J. DE la "Religious Persecution, Anticlerical Tradition and Revolution: On Atrocities against the Clergy during the Spanish Civil War", Journal of Contemporary History, 33 (1998), pp. 355-369.

Delgado, M. "Anticlericalismo, espacio y poder. La destrucción de los rituales católicos, I93 I-1939”, in Cruz, El anticlericalismo, pp. I49-180.

Delgado, M. La ira sagrada. Anticlericalismo, iconoclastia y antirritualismo en la España contemporánea (Barcelona, I992).

Delgado, M. Las palabras de otro hombre. Anticlericalismo y misoginia (Barcelona, I993). 
Delgado Ruiz, M. “La antirreligiosidad popular en España”, in Álvarez Santaló, La religiosidad popular, pp. 499-5I4.

Esteban, José Refranero anticlerical (Madrid, I994).

Gallego, José Andrés “Sobre las formas de pensar y de ser”, in Historia General de España y América, vol i6-i (Madrid, I982), pp. 283-382.

Gilmore, David “The Anticlericalism of the Andalusian Rural Proletarians”, in Álvarez Santaló, La religiosidad popular, pp. 478-498.

Gilmore, David The People of the Plain: Class and Community in Lower Andalusia (New York, I980).

Goldberg, Harriet Motif - Index of Medieval Spanish Folk Narratives (Binghamton, NY, I996).

Gómez Molleda, Dolores Los reformadores de la España contemporánea (Madrid, I 98 I).

Jackson, G., et al. Octubre 1934. Cincuenta años para la reflexión (Madrid, I985).

Lannon, Frances Privilegio, persecución y profecía. La Iglesia católica en España, I875-I975 (Madrid, I987).

Lincoln, Bruce "Revolutionary Exhumations in Spain, July i936", Comparative Studies in Society and History, 27 (1985), pp. 24I-260; Spanish translation: "Exhumaciones revolucionarias en España, julio I936", Historia Social, 35 (1999), PP. IOI-II 8 .

Mateo, Elías de Anticlericalismo en Málaga, I874-I923 (Málaga, I990).

Mintz, Jerome R. The Anarchist of Casas Viejas (Chicago, IL [etc.], I982).

Mitchell, Timothy Betrayal of the Innocents: Desire, Power, and the Catholic Church in Spain (Philadelphia, PA, I998).

Molina Martínez, José Luis Anticlericalismo y literatura en el siglo XIX (Murcia, I998).

Moliner Prada, A. “Anticlericalismo y revolución liberal (i833-I874)”, in La Parra López and Suárez Cortina, El anticlericalismo español contemporáneo, pp. $69-125$.

Montero, Antonio La persecución religiosa en España, I936-1939 (Madrid, I96I).

Nakens, José “Inmodestia”, in Nakens, Yo, hablando de mí, pp. 26-30.

Nakens, José Yo, hablando de mí (Colección de artículos) (Madrid, I9I4).

Pan Montojo, Juan (ed.) Más se perdió en Cuba. España, I 898 y la crisis de fin de siglo (Madrid, I998).

Parra López, E. La and Suárez Cortina, M. (eds) El anticlericalismo español contemporáneo (Madrid, I998).

Parra López, E. LA "Los inicios del anticlericalismo español contemporáneo", in La Parra López and Suárez Cortina, El anticlericalismo español contemporáneo, pp. I7-68.

PÉrez Garzón, J.S. "Curas y liberales en la revolución burguesa”, in Cruz, El anticlericalismo, pp. 67-100.

Pérez Ledesma, M. “El Estado y la movilización social en el siglo XIX español”, in Castillo and Ortiz de Orruño, Estado, protesta y movimientos sociales, pp. 2 I 5 $23 \mathrm{I}$.

Pérez Ledesma, M. “José Nakens (I84I-I926): Pasión anticlerical y activismo republicano", in Burdiel and Pérez Ledesma, Liberales, agitadores y conspiradores, pp. $30 \mathrm{I}-330$. 
Pérez Ledesma, M. “La sociedad española, la guerra y la derrota”, in Pan Montojo, Más se perdió en Cuba, pp. 9I-I49.

PitT-Rivers, Julian The People of the Sierra (London, I954); Spanish translation: Un pueblo de la sierra: Grazalema (Madrid, I989).

RANZATO, GABRIEle "Dies Irae: La persecuzione religiosa nella zona repubblicana durante la guerra civile spagnola (1936-1939)”, Movimento Operaio e Socialista, 2 (I988), pp. 59-72.

Revuelta González, M. El anticlericalismo español en sus documentos (Barcelona, 1999).

Romero Maura, J. La rosa de fuego. El obrerismo barcelonés de I898 a I909 (Barcelona, I974).

Rueda, Germán (ed.) Doce estudios de historiografía contemporánea (Santander, I99I).

Salomón Chéliz, Pilar "La crítica moral al orden social: la persistencia del anticlericalismo en la sociedad española, I900-1939" (unpublished doctoral thesis, Zaragoza, I996).

Salomón, Pilar "Poder y ética. Balance historiográfico sobre anticlericalismo", Historia Social, i 9 (1994), pp. I I 3- I 28.

Salomón Chéliz, Pilar "Republicanismo y rivalidad con el clero: movilización de la protesta anticlerical en Aragón, 1900-1913", Studia Historica, Historia Contemporánea, I7 (1999), pp. 2 I I-229.

Sánchez, José M. The Spanish Civil War as a Religious Tragedy (Notre Dame, IN, I 978).

Santirso, M. "De repente, el verano de i 835”, Historia Social, 34 (I999), pp. 3-26.

SuÁrez Cortina, M. “Anticlericalismo, religión y política durante la Restauración”, in La Parra López and Suárez Cortina, El anticlericalismo español contemporáneo, pp. I 27-2 IO.

SuÁrez Cortina, M. (ed.) La cultura española en la Restauración (Santander, 1999).

Tarrow, Sidney Power in Movement: Social Movements, Collective Action and Politics (Cambridge [etc.], I994); Spanish translation: El poder en movimiento. Los movimientos sociales, la acción colectiva y la política (Madrid, I997).

Ullman, Joan Connelly La Semana Trágica. Estudio sobre las causas socioeconómicas del anticlericalismo en España (I898-19I2) (Barcelona, I972). 